\title{
Pharmaciana
}

Vol. 8, No.1, May 2018, Page. 119-128

ISSN: 2088 4559; e-ISSN: 24770256

DOI: $10.12928 /$ pharmaciana.v8i1.7633

\section{Comparison of carbopol 934 and 941 as thickeners on ketoconazole microemulsions based on physical stability}

\author{
Pramulani Mulya Lestari*, Kori Yati, Nanda Savira \\ Fakultas Farmasi dan Sains, Universitas Muhammadiyah Prof. DR. HAMKA \\ Jl. Delima II/IV Jakarta, Indonesia
}

Submitted: 02-03-2018

Reviewed: 09-03-2018

Accepted: 08-05-2018

\begin{abstract}
As a drug delivery system, ketoconazole microemulsion in virgin coconut oil (oil phase) is added with a thickening agent to create transdermal dosage form. This study aimed to compare the physical stabilities of ketoconazole microemulsions formed with different thickeners, namely Carbopol 934 and Carbopol 941. The formula used varying concentrations of Carbopol 934 and Carbopol 941 , i.e., $0.15 \%$ and $0.25 \%$. The stability was observed during eight-week storage in which the conditions were controlled by different degrees of temperature, i.e., $4^{0} \mathrm{C}, 25-30^{\circ} \mathrm{C}$ (room temperature), and $40^{\circ} \mathrm{C}$. The stability tests included organoleptic observation, $\mathrm{pH}$, surface tension, viscosity, particle size, and zeta potential. Based on the Kruskal-Wallis test results, ketoconazole microemulsion with Carbopol 941 that had been stored in different temperature showed a significant difference in particle size (significance value $<0.05$ ), but it did not apply to Carbopol 934. The evaluation revealed that compared to $0.25 \%$ of Carbopol 934, microemulsion with $0.15 \%$ of Carbopol 934 had a smaller difference between the time intervals. This research concluded that the use of $0.15 \%$ of Carbopol 934 as a thickener in ketoconazole microemulsion had better physical stability compared to Carbopol 941 due to the influence of temperature and length of storage.
\end{abstract}

Keywords: physical stability, ketoconazole microemulsion, thickener, Carbopol 934, and Carbopol 941

\footnotetext{
Corresponding author:

Pramulani Mulya Lestari

Fakultas Farmasi dan Sains, Universitas Muhammadiyah Prof. DR. HAMKA

Jl. Delima II/IV Perumnas Klender Jakarta Timur

Email: pramulani_mlestari@uhamka.ac.id
} 


\section{INTRODUCTION}

Ketoconazole is a topically and orally administered antifungal. In oral administration, ketoconazole may inhibit the liver enzyme CYP3A4 cytochrome P450 isoenzyme, causing hepatotoxicity when used in large doses for more than one month. Meanwhile, in topical application, it is not associated with hepatotoxic risk because the amount absorbed by the body is considerably low (Sweetman, 2009). To optimize drug absorption in the skin, ketoconazole is created in the form of microemulsion and treatment with large doses is reduced to minimize hepatotoxic side effects. Microemulsion is a thermodynamically stable system with transparent (translucent) color and low viscosity; it is a dispersion of oil and water stabilized by the film of surfactant molecules (Agoes 2012).

As a drug delivery system, ketoconazole microemulsion in virgin coconut oil (oil phase) is added with a thickening agent to create a transdermal dosage form. The addition of Carbopol as a thickener aims to improve physical stability, avoid the use of Tween 80 with large concentration, and increase the viscosity of ketoconazole microemulsions; hence, increasing the comfort in topical application. Aside from being stable at high temperature, Carbopol is a good and efficient thickening agent even when used in low concentration, which allows its use as a suspending agent and stabilizer in emulsions, pastes, ointments, and gels (Jeon, 2007 in Ben et al., 2013). Carbopol 941 and Carbopol 934 are used because at the same concentration their viscosity is lower than Carbopol 940 (Rowe et al., 2009). Carbopol 941 is cross-linked with allyl ethers of pentaerythritol, while Carbopol 934 is cross-linked with allyl ethers of sucrose (United States Pharmacopeial Convention, 2007). Carbopol gives dosage form a high viscosity capable of slowing the droplet movement, which consequently reduces the rate or speed of dosage form separation and induces stability (Ben et al., 2013).

\section{MATERIALS AND METHODS}

\section{Material}

The materials used in this research were virgin coconut oil from PT Herban Bagoes, Carbopol 934 from PT Shrec Chemicals, and Carbopol 941 from PT Zhongtang (Dalian) Materials.

\section{Method}

Examining the characteristics of virgin coconut oil

This examination included organoleptic analysis and specific gravity test of virgin coconut oil. The organoleptic analysis was carried out by observing the shape, color, and odor.

\section{Creating microemulsion dosage form (Arfiani 2010)}

Table I. The formula of virgin coconut oil (VCO) microemulsion

\begin{tabular}{lcc}
\hline Components & \% & Functions \\
\hline Ketoconazole & 0.4 & Active substance \\
VCO & 5 & Oil phase \\
Tween 80 & 35 & Surfactant \\
Sorbitol & 10 & Cosurfactant \\
Nipagin & 0.18 & Preservative \\
Nipasol & 0.02 & Preservative \\
Aquadestilata ad & 100 & Water phase \\
\hline
\end{tabular}

Tween 80 was dissolved in aquadest that was heated to $60^{\circ} \mathrm{C}$ (M1). Nipagin and Nipasol were dissolved also dissolved in heated aquadest (M2). Ketoconazole was dissolved in virgin coconut oil (oil phase). M2 was mixed with M1 (water phase). The oil phase was added to the water phase and stirred with a magnetic stirrer at $500 \mathrm{rpm}$ for 15 minutes. The temperature was maintained lower than 
or equal to $40^{\circ} \mathrm{C}$. Then, sorbitol was added dropwise while stirred with a magnetic stirrer at $500 \mathrm{rpm}$ for 15 minutes.

Creating microemulsion dosage form with thickening agent (Arvindbhai et al., 2014)

Table II. The formula of ketoconazole microemulsion with Carbopol as thickener

\begin{tabular}{lllllll}
\hline Components & F1 & F2 & F3 & F4 & F5 & Functions \\
\hline Carbopol 934 & - & $0.15 \mathrm{~g}$ & $0.25 \mathrm{~g}$ & - & - & Thickening agent \\
Carbopol 941 & - & - & - & $0.15 \mathrm{~g}$ & $0.25 \mathrm{~g}$ & Thickening agent \\
50\% TEA Solution & - & $0.3 \mathrm{~mL}$ & $0.6 \mathrm{~mL}$ & $0.3 \mathrm{~mL}$ & $0.6 \mathrm{~mL}$ & $\mathrm{pH}$ neutralizer \\
Aquadest & - & ad $10 \mathrm{~mL}$ & ad $10 \mathrm{~mL}$ & ad $10 \mathrm{~mL}$ & ad $10 \mathrm{~mL}$ & Dispersant \\
Microemulsion & $100 \mathrm{~mL}$ & $90 \mathrm{~mL}$ & $90 \mathrm{~mL}$ & $90 \mathrm{~mL}$ & $90 \mathrm{~mL}$ & Microemulsion \\
\hline
\end{tabular}

Carbopol was dispersed in aquadest and left for 24 hours. Afterward, it was added with $50 \%$ TEA solution until the $\mathrm{pH}$ reached 5.5 and, then, stirred until homogeneous. The microemulsion produced in Point 2 was mixed with the thickening base using a magnetic stirrer at $300 \mathrm{rpm}$ for 15 minutes at room temperature.

\section{Measuring diameter in spreadability test (Lateh, 2015)}

A sample of 0.5 gram was placed in the middle of the first petri dish, which was attached to a graph (millimeter) paper. The diameter was measured by placing a 46-gram petri dish on top of the first petri dish. The spreadability was determined based on the diameter of the sample that had spread to two directions after 1 minute. Then, another weight (i.e., 50 gram) was added to it until a constant spreadability was obtained. The diameter of the spread was measured after 1 minute.

\section{Examining the physical stability of microemulsion}

Phase separation (Gozali et al., 2009)

This test was performed with six cycles (cycling test). Each cycle consisted of a dosage form stored at $4^{0} \mathrm{C} \pm 2^{\circ} \mathrm{C}$ for 48 hours. It was later stored at the same temperature for the next 48 hours. In this test, the indications of separation were observed organoleptically.

\section{Physical stability (Natalia, 2012)}

In this test, the dosage forms were stored at different temperatures, namely $4^{\circ} \mathrm{C} \pm 2{ }^{\circ} \mathrm{C}, 25-30^{\circ} \mathrm{C}$ $\pm 2^{\circ} \mathrm{C}$ (room temperature), and $40^{\circ} \mathrm{C} \pm 2^{\circ} \mathrm{C}$, for eight weeks. Afterward, they were evaluated every two weeks. The evaluation included organoleptic test, $\mathrm{pH}$, surface tension, viscosity, zeta potential, and particle size.

\section{Organoleptic test}

The microemulsion dosage form was observed for any discoloration, changes in odor and clarity, as well as any changes that might occur during storage.

\section{pH measurement (Departemen Kesehatan RI, 2014)}

The $\mathrm{pH}$ was measured with $\mathrm{pH}$ meter at a temperature of $25^{\circ} \mathrm{C} \pm 2^{0} \mathrm{C}$ by washing the electrode, rinsing it with distilled water, and letting it dry. The $\mathrm{pH}$ meter was calibrated using standard buffer solutions with $\mathrm{pH} 4$ and $\mathrm{pH}$ 7. The electrode was inserted into the microemulsion, and the $\mathrm{pH}$ was recorded. 


\section{Viscosity test}

The viscosity of the dosage form was measured using the Brookfield LVDVE Viscometer at room temperature $\left(25^{\circ} \mathrm{C} \pm 2^{0} \mathrm{C}\right)$. The microemulsion was put into a $250 \mathrm{~mL}$ beaker glass, attached with Spindle No. 63 for F1 and Spindle No. 64 for F2-F5, and set until the fill line of the spindle was covered with the samples. The speed for F1 was $20 \mathrm{rpm}$, while the one for F2-F5 was $10 \mathrm{rpm}$. The viscosity was recorded after 2 minutes, and three readings were performed.

\section{Surface tension measurement (Voigt, 1995)}

The surface tension was measured with the Du Noüy ring method, which used a tensiometer that had been calibrated previously. The ring was attached to the latches of the measurement system without contact with the test liquid. The table with the test liquid was raised toward the holder until the ring was 2-3 $\mathrm{mm}$ below the surface of the ring. The table and the test liquid were moved downward slowly until the ring was lifted from the solution. The force was determined by measuring the turning angle of the circular wire used to pull out the platinum-iridium ring from the effect of interfacial forces.

\section{Particle size and zeta potential (Martin et al., 1993; Voigt, 1995)}

The sample $(1 \mathrm{~mL})$ was diluted with aquadest $(9 \mathrm{~mL})$. The particle size and the zeta potential were measured with DelsaMax PRO light scattering analyzer. The solution was put into the flow cell, which then inserted into the cell in the equipment. The analyzer was turned on, and the DLS \& PALS (Simultaneous) menu was selected. After 9 minutes, it produced a set of data consisting of particle size and zeta potential.

\section{RESULTS AND DISCUSSION}

The characteristics of virgin coconut oil

The characteristics of the virgin coconut oil met the requirements or the standards set in the Farmakope Indonesia Edition III.

Table III. The evaluation results of the characteristics of virgin coconut oil

\begin{tabular}{clc}
\hline \multicolumn{1}{c}{ Evaluations } & \multicolumn{1}{c}{ Results } & Standard of FI III \\
\hline Organoleptic Test & $\begin{array}{l}\text { a. Shape: Liquid } \\
\text { b. Color: Clear }\end{array}$ & $\begin{array}{c}\text { Liquid } \\
\text { Clear }\end{array}$ \\
& $\begin{array}{l}\text { c. Smell: Weak smell, } \\
\text { typical of coconut } \\
\text { oil }\end{array}$ & Odorless or weak smell \\
& $0.9496 \mathrm{~g} / \mathrm{mL}$ & $0.940-0.950 \mathrm{~g} / \mathrm{mL}$ \\
\hline
\end{tabular}

\section{Spreadability}

The spreadability of microemulsion without thickening agent (F1) was higher (i.e., $6.80 \mathrm{~cm}$ ) than with thickening agent $(\mathrm{F} 2-\mathrm{F} 5=4.4-6.3 \mathrm{~cm})$. 
Table IV. The spreadability test results of ketoconazole microemulsion with Carbopol as thickener

\begin{tabular}{ccc}
\hline Formulas & $\begin{array}{c}\text { Diameters with 46-gram Weight } \\
(\mathbf{c m} \pm \text { SD) }\end{array}$ & $\begin{array}{c}\text { Diameters with 50-gram Weight } \\
(\mathbf{c m} \pm \text { SD) }\end{array}$ \\
\hline F1 & $6.30 \pm 0.4$ & $6.80 \pm 0.4$ \\
F2 & $6.00 \pm 0.2$ & $6.30 \pm 0.4$ \\
F3 & $4.20 \pm 0.2$ & $5.00 \pm 0.3$ \\
F4 & $4.50 \pm 0.2$ & $5.30 \pm 0.2$ \\
F5 & $3.80 \pm 0.2$ & $4.40 \pm 0.2$ \\
\hline
\end{tabular}

There is a structural difference between Carbopol 941 and 934. Carbopol 941 is cross-linked with allyl ethers of pentaerythritol, while Carbopol 934 is cross-linked with allyl ethers of sucrose (United States of Pharmacopeial Convention, 2007). The decrease in spreadability occurs because the viscosity of the dosage form increases (Pramitasari, 2011). A high viscosity makes the dosage form difficult to flow and, thereby, spread.

\section{Organoleptic observation results}

At a temperature of $4^{0} \mathrm{C}$, microemulsion without thickening agent (F1) became more viscous in Week 2. At the same temperature, microemulsion with $0.15 \%$ of Carbopol 934 gelatinized in Week 4. It had a higher viscosity than before it was stored at $4^{\circ} \mathrm{C}$. The particles tended to merge and form bonds with denser ones, resulting in increased viscosity and decreased flow rate (Dewi, 2010). However, when the microemulsion was restored at room temperature, it returned to its original state, i.e., dilute and easily poured. Microemulsion with $0.25 \%$ of Carbopol 934 showed formal changes at $40^{\circ} \mathrm{C}$ in Week 8 . It had a lower viscosity than before it was stored at $40^{\circ} \mathrm{C}$. The particles of the microemulsion tend to stretch at high temperature and, thereby, widen the space between them. Consequently, viscosity decreases as flow rate increases.

\section{Phase separation}

This research used cycling test with six cycles. The physical feature, particularly the occurrence of phase separation, of the microemulsion was then observed. After the six cycles, there was no difference between the microemulsions prepared with different formulas. They remained clear in color, indicating that all formulas in this research produced stable microemulsions with reversible change.

\section{Surface tension}

Microemulsion without thickener had lower surface tension (i.e., 30.3 dyne/cm) than the one with a thickening agent (i.e., 39.5-57.1 dyne/cm). Microemulsion with Carbopol 934 had stronger surface tension than Carbopol 941 because, even with the same concentration, the viscosity of Carbopol 934 was higher than Carbopol 941. Changes in surface tension occurred in all three temperatures. The surface tension decreased every two weeks (time interval of observation). The results of nonparametric analysis showed that the length of storage affected the surface tension of microemulsion, except for the one without a thickening agent. This analysis also found that microemulsion with a thickener (F2, F3, and F5) was not dependent on temperature, except for the one with $0.15 \%$ of Carbopol 941 (F4) and without a thickening agent (F1). 
Table V. The surface tension of ketoconazole microemulsion with carbopol as thickener at a temperature of $4^{\circ} \mathrm{C}$

\begin{tabular}{cccccc}
\hline \multirow{2}{*}{ Formulas } & \multicolumn{5}{c}{ Time (week) } \\
\cline { 2 - 6 } & $\mathbf{0}$ & $\mathbf{2}$ & $\mathbf{4}$ & $\mathbf{6}$ & $\mathbf{8}$ \\
\hline F1 & $30.3 \pm 0.25$ & $31.0 \pm 0.61$ & $34.6 \pm 0.51$ & $35.1 \pm 0.66$ & $35.8 \pm 0.25$ \\
F2 & $39.5 \pm 0.12$ & $36.1 \pm 0.12$ & $34.5 \pm 0.76$ & $32.9 \pm 0.60$ & $28.1 \pm 1.01$ \\
F3 & $57.1 \pm 0.38$ & $50.8 \pm 0.25$ & $45.8 \pm 0.23$ & $43.5 \pm 0.47$ & $42.4 \pm 0.10$ \\
F4 & $42.8 \pm 0.21$ & $41.1 \pm 0.29$ & $37.1 \pm 0.10$ & $33.6 \pm 0.06$ & $32.6 \pm 0.35$ \\
F5 & $47.0 \pm 0.35$ & $46.2 \pm 0.36$ & $42.8 \pm 0.75$ & $40.2 \pm 0.32$ & $38.6 \pm 0.87$ \\
\hline
\end{tabular}

Table VI. The surface tension of ketoconazole microemulsion with Carbopol as thickener at room temperature $\left(25-30^{\circ} \mathrm{C}\right)$

\begin{tabular}{cccccc}
\hline \multirow{2}{*}{ Formulas } & \multicolumn{5}{c}{ Time (week) } \\
\cline { 2 - 6 } & $\mathbf{0}$ & $\mathbf{2}$ & $\mathbf{4}$ & $\mathbf{6}$ & $\mathbf{8}$ \\
\hline F1 & $30.3 \pm 0.25$ & $32.5 \pm 0.44$ & $33.5 \pm 0.61$ & $34.4 \pm 1.00$ & $35.1 \pm 0.76$ \\
F2 & $39.5 \pm 0.12$ & $38.8 \pm 0.25$ & $36.5 \pm 0.20$ & $34.2 \pm 0.80$ & $33.5 \pm 1.15$ \\
F3 & $57.1 \pm 0.38$ & $52.8 \pm 0.55$ & $47.2 \pm 0.49$ & $38.6 \pm 0.51$ & $36.5 \pm 0.42$ \\
F4 & $42.8 \pm 0.21$ & $42.2 \pm 0.26$ & $41.8 \pm 0.29$ & $39.0 \pm 0.50$ & $38.0 \pm 0.17$ \\
F5 & $47.0 \pm 0.35$ & $46.5 \pm 0.25$ & $44.5 \pm 0.51$ & $41.1 \pm 0.74$ & $40.5 \pm 0.45$ \\
\hline
\end{tabular}

Table VII. The surface tension of ketoconazole microemulsion with carbopol as thickener at a temperature of $40^{\circ} \mathrm{C}$

\begin{tabular}{cccccc}
\hline \multirow{2}{*}{ Formulas } & \multicolumn{5}{c}{ Time (week) } \\
\cline { 2 - 6 } & $\mathbf{0}$ & $\mathbf{2}$ & $\mathbf{4}$ & $\mathbf{6}$ & $\mathbf{8}$ \\
\hline F1 & $30.3 \pm 0.25$ & $29.5 \pm 0.36$ & $27.5 \pm 0.31$ & $26.4 \pm 0.45$ & $24.9 \pm 1.33$ \\
F2 & $39.5 \pm 0.12$ & $35.9 \pm 0.46$ & $34.6 \pm 0.79$ & $31.3 \pm 1.18$ & $28.1 \pm 1.68$ \\
F3 & $57.1 \pm 0.38$ & $53.7 \pm 1.01$ & $48.7 \pm 3.34$ & $35.8 \pm 0.21$ & $34.9 \pm 1.14$ \\
F4 & $42.8 \pm 0.21$ & $41.9 \pm 0.44$ & $41.5 \pm 0.47$ & $38.6 \pm 0.51$ & $37.1 \pm 0.58$ \\
F5 & $47.0 \pm 0.35$ & $42.3 \pm 0.52$ & $41.8 \pm 0.32$ & $41.1 \pm 0.55$ & $39.7 \pm 0.26$ \\
\hline
\end{tabular}

\section{Viscosity}

Microemulsion without thickener had a lower viscosity (i.e., 1,268 cps) than the one with a thickening agent (i.e., 4,364-46,197 cps). The viscosity of microemulsions stored at three different temperatures changed in every time of observation. It increased because the structure of microemulsion became more dense during the storage. The globules were difficult to move due to the narrow space between the particles. Meanwhile, the decreased viscosity was affected by the temperature rise. High temperature can reduce viscosity (Ben et al., 2013). 
Table VIII. The viscosity of ketoconazole microemulsion with carbopol as thickener at a temperature of $4^{\circ} \mathrm{C}$

\begin{tabular}{cccccc}
\hline \multirow{2}{*}{ Formulas } & \multicolumn{5}{c}{ Time (week) } \\
\cline { 2 - 6 } & $\mathbf{0}$ & $\mathbf{2}$ & $\mathbf{4}$ & $\mathbf{6}$ & $\mathbf{8}$ \\
\hline F1 & $1,268 \pm 79$ & $3,334 \pm 120$ & $3,977 \pm 56$ & $4,788 \pm 22$ & $5,653 \pm 10$ \\
F2 & $4,364 \pm 42$ & $9787 \pm 42$ & $13,540 \pm 67$ & $15,866 \pm 16$ & $20,108 \pm 17$ \\
F3 & $46,197 \pm 23$ & $285,433 \pm 13$ & $357,633 \pm 14$ & $459,633 \pm 18$ & $503,888 \pm 35$ \\
F4 & $27,450 \pm 35$ & $33,743 \pm 53$ & $51,517 \pm 67$ & $56,277 \pm 11$ & $58,655 \pm 32$ \\
F5 & $43,950 \pm 20$ & $48,357 \pm 61$ & $71,400 \pm 62$ & $81,443 \pm 55$ & $89,519 \pm 11$ \\
\hline
\end{tabular}

Table IX. The viscosity of ketoconazole microemulsion with Carbopol as thickener at a temperature of $25-30^{\circ} \mathrm{C}$

\begin{tabular}{cccccc}
\hline \multirow{2}{*}{ Formulas } & \multicolumn{5}{c}{ Time (week) } \\
\cline { 2 - 6 } & $\mathbf{0}$ & $\mathbf{2}$ & $\mathbf{4}$ & $\mathbf{6}$ & $\mathbf{8}$ \\
\hline F1 & $1,268 \pm 79$ & $939 \pm 39$ & $889 \pm 23$ & $781 \pm 15$ & $709 \pm 12$ \\
F2 & $4,364 \pm 42$ & $3,366 \pm 12$ & $2,664 \pm 28$ & $1,844 \pm 13$ & $1,745 \pm 45$ \\
F3 & $46,197 \pm 22$ & $30,630 \pm 11$ & $25,323 \pm 61$ & $17,220 \pm 38$ & $15,187 \pm 46$ \\
F4 & $27,450 \pm 35$ & $27,117 \pm 46$ & $26,737 \pm 12$ & $19,987 \pm 45$ & $16,638 \pm 36$ \\
F5 & $43,950 \pm 20$ & $34,197 \pm 50$ & $34,003 \pm 470$ & $29,643 \pm 50$ & $29,103 \pm 32$ \\
\hline
\end{tabular}

Table X. The viscosity of ketoconazole microemulsion with carbopol as thickener at a temperature of $40^{\circ} \mathrm{C}$

\begin{tabular}{cccccc}
\hline \multirow{2}{*}{ Formulas } & \multicolumn{5}{c}{ Time (week) } \\
\cline { 2 - 6 } & $\mathbf{0}$ & $\mathbf{2}$ & $\mathbf{4}$ & $\mathbf{6}$ & $\mathbf{8}$ \\
\hline F1 & $1,268 \pm 79$ & $378 \pm 39$ & $361 \pm 33$ & $324 \pm 38$ & $302 \pm 24$ \\
F2 & $4,364 \pm 42$ & $3,574 \pm 9$ & $2,406 \pm 88$ & $1,642 \pm 95$ & $945 \pm 10$ \\
F3 & $46,197 \pm 22$ & $11,627 \pm 39$ & $10,636 \pm 50$ & $10,467 \pm 67$ & $8,400 \pm 23$ \\
F4 & $27,450 \pm 35$ & $21,458 \pm 243$ & $15,533 \pm 50$ & $14,407 \pm 72$ & $13,473 \pm 94$ \\
F5 & $43,950 \pm 20$ & $40,070 \pm 11$ & $38,470 \pm 20$ & $38,030 \pm 27$ & $34,503 \pm 66$ \\
\hline
\end{tabular}

\section{Globular size}

Microemulsion without thickener had a smaller particle size (i.e., $12.63 \mathrm{~nm}$ ) compared to the one with a thickening agent (i.e., 21.53-57.67 nm). The dosage form with Carbopol 934 had a smaller particle size than the one with Carbopol 941. The structural difference between these two thickening agents affects the particle size of the dosage form even when they are applied with the same concentration. Particle size increases in temperature and time because the smaller particles merge into larger ones. Moreover, the closer distance between the adjacent particles enables the merging. The polydispersity index of microemulsions formed with different formulas and stored in varying degrees of temperature was 0.571 , categorized as monodisperse and relatively uniform. The nonparametric analysis results showed that the particle size in all formulas was not dependent on storage temperature, except in F4 and F5. It was dependent on the length of storage. 
Table XI. The globular size of ketoconazole microemulsion with carbopol as thickener at a temperature of $4^{\circ} \mathrm{C}$

\begin{tabular}{cccccc}
\hline \multirow{2}{*}{ Formulas } & \multicolumn{5}{c}{ Time (week) } \\
\cline { 2 - 6 } & $\mathbf{0}$ & $\mathbf{2}$ & $\mathbf{4}$ & $\mathbf{6}$ & $\mathbf{8}$ \\
\hline F1 & $12.63 \pm 1.10$ & $15.47 \pm 0.23$ & $18.13 \pm 1.04$ & $19.37 \pm 1.39$ & $22.37 \pm 3.25$ \\
F2 & $21.53 \pm 1.19$ & $33.80 \pm 0.61$ & $38.20 \pm 0.10$ & $40.83 \pm 0.85$ & $44.67 \pm 1.33$ \\
F3 & $26.27 \pm 1.39$ & $52.37 \pm 1.24$ & $60.30 \pm 0.44$ & $71.47 \pm 0.85$ & $77.47 \pm 0.25$ \\
F4 & $36.77 \pm 1.42$ & $44.87 \pm 0.40$ & $45.43 \pm 0.15$ & $46.77 \pm 0.40$ & $48.33 \pm 0.21$ \\
F5 & $57.67 \pm 0.58$ & $58.13 \pm 0.35$ & $60.60 \pm 0.62$ & $62.03 \pm 0.57$ & $68.33 \pm 0.61$ \\
\hline
\end{tabular}

Table XII. The globular size of ketoconazole microemulsion with carbopol as thickener at atemperature of $25-30^{\circ} \mathrm{C}$

\begin{tabular}{cccccc}
\hline \multirow{2}{*}{ Formulas } & \multicolumn{5}{c}{ Time (week) } \\
\cline { 2 - 6 } & $\mathbf{0}$ & $\mathbf{2}$ & $\mathbf{4}$ & $\mathbf{6}$ & $\mathbf{8}$ \\
\hline F1 & $12.63 \pm 1.10$ & $20.00 \pm 0.95$ & $26.23 \pm 0.35$ & $66.67 \pm 2.32$ & $74.03 \pm 1.11$ \\
F2 & $21.53 \pm 1.19$ & $41.30 \pm 0.66$ & $43.03 \pm 0.31$ & $43.30 \pm 0.40$ & $44.60 \pm 0.26$ \\
F3 & $26.27 \pm 1.39$ & $64.13 \pm 1.06$ & $67.83 \pm 0.23$ & $69.30 \pm 0.17$ & $70.00 \pm 0.10$ \\
F4 & $36.77 \pm 1.42$ & $47.57 \pm 0.93$ & $49.47 \pm 1.10$ & $53.50 \pm 0.10$ & $55.03 \pm 0.40$ \\
F5 & $57.67 \pm 0.58$ & $64.17 \pm 0.32$ & $68.97 \pm 0.38$ & $70.97 \pm 0.60$ & $72.50 \pm 0.40$ \\
\hline
\end{tabular}

Table XIII. The globular size of ketoconazole microemulsion with carbopol as thickener at a temperature of $40^{\circ} \mathrm{C}$

\begin{tabular}{cccccc}
\hline \multirow{2}{*}{ Formulas } & \multicolumn{5}{c}{ Time (week) } \\
\cline { 2 - 6 } & $\mathbf{0}$ & $\mathbf{2}$ & $\mathbf{4}$ & $\mathbf{6}$ & $\mathbf{8}$ \\
\hline F1 & $12.63 \pm 1.10$ & $16.03 \pm 1.80$ & $18.90 \pm 2.46$ & $60.17 \pm 1.07$ & $74.20 \pm 0.53$ \\
F2 & $21.53 \pm 1.19$ & $28.97 \pm 2.98$ & $36.67 \pm 0.51$ & $40.27 \pm 0.38$ & $55.20 \pm 1.84$ \\
F3 & $26.27 \pm 1.39$ & $41.00 \pm 1.66$ & $49.17 \pm 0.95$ & $62.10 \pm 0.53$ & $76.47 \pm 2.46$ \\
F4 & $36.77 \pm 1.42$ & $46.93 \pm 0.84$ & $55.13 \pm 0.71$ & $84.33 \pm 4.97$ & $98.00 \pm 1.32$ \\
F5 & $57.67 \pm 0.58$ & $123.57 \pm 1.89$ & $146.20 \pm 1.18$ & $164.17 \pm 2.50$ & $170.47 \pm 6.60$ \\
\hline
\end{tabular}

Microemulsion without thickener had smaller zeta potential (i.e., -7.97) compared to the one with a thickening agent (i.e., -9.33 to -14.51 ). The zeta potential in this research does not meet the desired criteria. The stability of an emulsion is categorically poor when its zeta potential is less than 30 . On the contrary, an emulsion is stable when the zeta potential is larger than 30 . The positive (+) and negative (-) values in zeta potential indicate the $\mathrm{pH}$ of the dosage form. The positive (+) value represents low pH (acid), while the negative (-) one shows high pH (base) (Ben et al., 2013). The zeta potential in this research was negative because the $\mathrm{pH}$ of the dosage form was 6.26-6.92 (base). The statistical analysis of the zeta potential showed that the microemulsion with thickener (F2, F3, F4, and F5) was not affected by temperature and length of storage. Meanwhile, the zeta potential of microemulsion without thickener $(\mathrm{F} 1)$ was dependent on temperature and length of storage.

\section{CONCLUSION}

This research concludes that the use of $0.15 \%$ of Carbopol 934 as a thickening agent in ketoconazole microemulsion gives better physical stability than Carbopol 941. 


\section{REFERENCES}

Agoes, G., 2012. Sediaan Farmasi Likuida-Semisolida. Ed. 7. Bandung: Penerbit ITB.

Arfiani, Y., 2010. Perbandingan Laju difusi Ketokonazol dalam Sediaan Mikroemulsi dan Makroemulsi Minyak kelapa Murni Menggunakan Tween 80 sebagai Surfaktan. Bachelor Thesis. Jakarta: Farmasi UHAMKA.

Arvindbhai, P.V., Makwana, S.B., Bhavna, A.P., and Shraddha, J.P., 2014. Formulation and characterization of microemulsion based gel of curcumin for the management of plaque psoriasis. Post Graduate of Pharmaceuticak Sciences. Sardar Patel University

Ben, E.S., Suardi, M., Chalid, T.J, and Yulianto, T., 2013. Optimasi nanoemulsi minyak kelapa sawit (Palm Oil) menggunakan sukrosa monoester. Prosiding Seminar Nasional Perkembangan Terkini Sains Farmasi dan Klinik II, pp. 31.

Departemen Kesehatan RI, 1979. Farmakope Indonesia III. Jakarta: Departemen Kesehatan RI.

Dewi, R.K., 2010. Optimasi formulasi mikroemulsi sediaan hormon testosteron undekanoat. Bachelor Thesis. Jakarta: Universitas Islam Negeri Syarif Hidayatullah

Gozali, D., Rusmiati, D., and Utama, P., 2009. Formulasi dan Uji Stabilitas Mikroemulsi Ketokonazol Sebagai Antijamur Candida albicans dan Tricophyton mentagrophytes.Jatinangor: Universitas Padjadjaran, Farmaka, 7(2):54-67.

Jeon, F.I.J., 2007. Development and formulation of carbomer 934 Pcontaining mucoadhesive pellets by fluid-bed techniques. Dissertation. Germany: Marthin Luther University Halle-Wittenberg.

Lateh, M.S., 2015. Formulasi sediaan gel tangan sanitizer ekstrak etanol buah asam gelugur sebagai antibakteri terhadap Staphylococcus aureus. Bachelor Thesis. Surakarta: Fakultas Farmasi Universitas Muhammadiyah.

Martin A, Swarbrick J, Cammarata A. 1993. Farmasi Fisik II. Edisi 3. UI Press. Terjemahan: Yoshita. Jakarta.

Natalia, M., 2012. Uji Stabilitas Fisik dan Uji Aktivitas Antibakteri Minyak Jintan Hitma (Nigella sativa L.) yang Diformulasikan sebagai sediaan Nanoemulsi Gel (Nanoemulgel). Bachelor Thesis. Jakarta: FMIPA Universitas Indonesia.

Pramitasari, M., 2011. Formulasi dan uji aktivitas antijamur krim minyak sereh (Cymbopogoncitrates (DC) Stapf.) dengan basis vanishing cream terhadap Candida albicans dengan metode sumuran. Bachelor Thesis. Jember: Universitas Jember.

Rowe, R.C, Paul, J.S, and Quinn, M.E., 2009. Handbook of Pharmaceutical Excipients Sixth Edition. Pharmaceutical Press and American Phamacists Assosiation. Grayslake \& Washington.

Sweetman, C.S., 2009. Martindale The Complete Drug Reference Thirty-sixth edition. ISSN 02635364. USA: Pharmaceutical Press.

United States Pharmacopeial Convention, 2007. United States Pharmacopeia and National Formulary (USP 30-NF 27). Rockville, MD: USPC

Voigt, R., 1995. Buku Pelajaran Teknologi Farmasi. Terjemahan: Soendani Noerono. Yogyakarta: Universitas Gajah Mada Press. 
